\title{
LOW FRICTION Ti-B COATINGS DEPOSITED BY DUAL BEAM IBAD METHOD FOR WEAR RESISTANT APPLICATIONS
}

\author{
POWŁOKI $T i$-B OSADZANE METODĄ DWUWIĄZKOWĄ IBAD \\ DO ZASTOSOWAŃ WYMAGAJĄCYCH \\ ODPORNOŚCI NA ZUŻYCIE
}

\author{
Agnieszka TWARDOWSKA ${ }^{1}$
}

\begin{abstract}
Thin Ti-B coatings of $500 \mathrm{~nm}$ in thickness were deposited by dual beam ion beam assisted deposition method (DB IBAD) on the surfaces of sintered $\alpha-\mathrm{Al}_{2} \mathrm{O}_{3}$ (with $1 \%$ vol. $\mathrm{MgO}$ ) cutting inserts. Deposition of Ti-B coating was conducted in vacuum. Two beams of Ar+ ions were applied of the same energy of $\sim 10 \mathrm{keV}$. First ion beam was directed to $\mathrm{TiB}_{2}$ target at angle $67^{\circ}$ and used for sputtering, the second one was directed perpendicularly to the surface of alumina substrate. XPS was applied to investigate chemical bonds in Ti-B coatings. Detailed spectra of B1s and Ti $2 \mathrm{p}$ indicated the presence of $\mathrm{TiB}_{2}$, $\mathrm{TiO}_{2}$ and $\mathrm{B}_{2} \mathrm{O}_{3}$. Mechanical properties of coated and uncoated alumina composites were examined by nanoindentation test using diamond indenter of Berkovich-type geometry, loaded in range $0.5 \mathrm{mN}$ to $50 \mathrm{mN}$. The friction- wear performance of coated alumina were examined in ball-on-disc test using an alumina and a $100 \mathrm{Cr} 6$ steel balls as counterparts, loaded at $1 \mathrm{~N}$. Cutting test was carried out in longitudinal turning of 100Cr6 steel shaft without use of any liquid coolant. Coated alumina inserts were harder and more resistant to wear than uncoated ones. The highest hardness of $45 \mathrm{GPa}$, was calculated by Oliver \& Pharr method for coated sample tested under the load of $1 \mathrm{mN}$. It was almost 3 times the value calculated for uncoated substrate $(16.5 \mathrm{GPa})$. The wear mechanism of Ti-B coated alumina was of abrasive type with alumina ball and of mixed abrasive and adhesive type in the case of friction contact with the steel ball. SEM observation of the surface of Ti-B coated alumina tools after turning revealed the presence of a liquid phase at the worn edge.
\end{abstract}

Keywords: Ti-B coating, dual beam IBAD method, wear resistance, superalloy

Streszczenie: Powłoki typu Ti-B o grubości $500 \mathrm{~nm}$ zostały nałożone metodą dwuwiązkową IBAD ( ion beam assisted deposition) na powierzchnie płytek skrawających wytworzonych na drodze spiekania proszków $\alpha-\mathrm{Al}_{2} \mathrm{O}_{3}$ (z dodatkiem $1 \%$ obj. MgO). Powłoki Ti-B nakładano w próżni $\left(10^{-4} \mathrm{~Pa}\right)$, stosując dwie wiązki jonów Ar+ o tej samej energii $\sim 10 \mathrm{keV}$. Pierwszą wiązkę jonów (rozpylającą) skierowano na powierzchnię tarczy $\mathrm{TiB}_{2}$ pod kątem $67^{\circ}$, drugą

\footnotetext{
${ }^{1}$ Institute of Technology, Pedagogical University, 2 Podchorazych St., 30-084 Krakow, Poland
} 
wiązkę jonów skierowano prostopadle do powierzchni podłoży korundowych. Wiązania chemiczne w otrzymanych powłokach Ti-B badano metodą XPS. Zarejestrowane widma szczegółowe $\mathrm{B} 1 \mathrm{~s}$ oraz Ti2p wskazały na obecność $\mathrm{TiB}_{2}$ oraz tlenków $\mathrm{TiO}_{2} \mathrm{i} \mathrm{B}_{2} \mathrm{O}_{3}$. Właściwości mechaniczne podłoży z powłoką Ti-B oraz bez powłoki określono metodą nanoindentacji przy użyciu wgłębnika o geometrii Berkovicha, w zakresie obciążeń od $0,5 \mathrm{mN}$ do $50 \mathrm{mN}$. Właściwości tribologiczno-zużyciowe określono w teście zużycia w geometrii kula-tarcza (ball-on-disc test) przy użyciu kulki korundowej oraz stalowej 100Cr6 (jako przeciwpróbki) przy obciążeniu $1 \mathrm{~N}$. Testy skrawności przeprowadzono podczas toczenia wzdłużnego wałka ze stali $100 \mathrm{Cr} 6$ bez stosowania cieczy chłodzącosmarujących. Twardość i odporność na zużycie ścierne płytek z powłoką Ti-B były wyższe w porównaniu do płytek referencyjnych (bez powłoki). Najwyższą twardość $45 \mathrm{GPa}$, obliczono metodą Olivier \& Phaar'a dla płytek z powłoką Ti-B przy obciążeniu wgłębnika $1 \mathrm{mN}$, co stanowiło niemal trzykrotnie wyższą wartość w stosunku do twardości zmierzonej dla podłoży bez powłoki (16,5 GPa). Zużycie płytek z powłoką w kontakcie ciernym z przeciwpróbką korundową miało charakter ścierny, a w przypadku współpracy z kulką stalową- miało charakter mieszany: ścierno-adhezyjny. Obserwacje SEM powierzchni narzędzi pokrytych powłoką Ti-B w obszarze krateru powstałego w próbie skrawności wykazały obecność fazy ciekłej na krawędzi zużytych ostrzy.

Słowa kluczowe: powłoka Ti-B, metoda dwuwiązkowa IBAD, odporność na zużycie, nadstop

\section{INTRODUCTION}

The chemical and wear resistance of $\alpha-\mathrm{Al}_{2} \mathrm{O}_{3}$ accompanied by its thermal stability makes this ceramic the most widely used tool material for dry cutting carried out at moderate and high speeds $[1,2]$. Machining without the use of expensive and hazardous coolant lubricants is preferred by the industry due to economical and ecological benefits. But such operating conditions are extremely difficult for the cutting tool materials, because of high friction present in the contact area between a tool and a workpiece which results in a strong temperature increase of the tool [3]. To enhance the resistance of alumina to thermal shocks and to improve its toughness, cutting tools based on $\alpha-\mathrm{Al}_{2} \mathrm{O}_{3}$ are reinforced with addition of a second phase. The most common reinforcements are: zirconium oxide $\mathrm{ZrO}$, titanium carbide $\mathrm{TiC}_{\mathrm{x}}$, silicon carbide $\mathrm{SiC}$, titanium nitride $\mathrm{TiN}$ and titanium diboride $\mathrm{TiB}_{2}[1,2,4]$. The addition titanium diboride is advantageous for mechanical properties of alumina- based sinters, but it is also beneficial for their tribological properties. $\mathrm{TiB}_{2}$ is almost two times harder than alumina (35 GPa). It is characterized by relatively low density $\left(\sim 4.5 \mathrm{~g} / \mathrm{cm}^{3}\right)$, high melting point $(3490 \mathrm{~K})$, excellent thermal stability up to $2000 \mathrm{~K}$, good electrical and thermal conductivity and good tribological and wear performance [5]. Until now, commercial application of titanium diboride is strongly limited by the anisotropy of its thermal expansion coefficient. It is thought to be the main source of an internal stress, generated during processing or heat treatment of this boride. Thus $\mathrm{TiB}_{2}$ sinters and coatings are highly susceptible to brittle cracking [6]. In the case of alumina composites, the addition of titanium diboride is limited up to $10 \%$ vol. At higher $\mathrm{TiB}_{2}$ contents, a decreased toughness of these composites is observed [7]. Composites containing less than $10 \%$ of titanium diboride are characterized by increased hardness but the content of this phase is insufficient to decrease the friction coefficient of the composite effectively. 
To reduce the friction and dissipate a heat generated during dry machining, solid lubricants can be applied. Solid lubricants are possible to be introduced in area of friction contact by coating the surface of tool, as one of the component of deposit [8]. To provide a low coefficient of friction, solid lubricant must be carefully chosen. The friction-wear conditions for operating of the tool must be taken into account, as the friction coefficient of all known solid lubricants can vary even over a wide range depending on material used as a counterpart, an applied load, a temperature and an environment. Diamond-like carbon DLC and $\mathrm{MoS}_{2}$ are of highest potential to be used in tribological applications as solid lubricants, because of their extremely low coefficient of friction, but obtained only in some conditions [7]. Ultra low friction coefficients of 0.01 for DLC and 0.02 for $\mathrm{MoS}_{2}$ indicate this coatings as ideal for dry machining, but only at high vacuum, inert or dry nitrogen environments [8]. In humidity, the most common friction- wear contacts environment, the friction coefficients of both DLC and $\mathrm{MoS}_{2}$ coatings arise to 0.5 , or more [9]. In the case of DLC coatings there are some other limitations of its application as solid lubricant which stem from chemical affinity of carbon to ferrous metals and high level of intrinsic stresses built-up during deposition DLC coatings. Depending on deposition method and its parameters the intrinsic stress in DLC coatings can reach several $\mathrm{GPa}[8,9,10]$. In result of it, the strong tendency to brittle cracking of DLC coatings is observed and it is difficult to produce them of reasonable thickness of at least 1 mikrometer. Additionally, DLC coatings have to be used in relatively low temperature, due to risk of graphitization, which can be activated at $250^{\circ} \mathrm{C}[10]$.

The presence of humidity in the machining environment is not always deleterious. Low friction coefficient in contact area and enhanced wear performance of such tools is obtained through formation of oxide products of friction-chemical reactions with humidity, resulting by lubricious, layered oxide products of Magnèli phases- type $[8,11,12]$. This beneficial effect of oxygen- rich environment is observed also in materials containing titanium $\left(\mathrm{Ti}_{3} \mathrm{SiC}_{2}, \mathrm{TiN}\right)$ or boron or both of this elements $\left(\mathrm{TiB}_{2}, \mathrm{Ti}(\mathrm{B}) \mathrm{N}\right)$ to make them "self-adaptive" to frictionwear conditions [13].

The aim of this work is to deposit Ti-B coatings by dual beam IBAD (Ion Beam Assisted Deposition) method and to investigate the influence of the coating on mechanical properties and friction- wear performance of the sintered $\alpha-\mathrm{Al}_{2} \mathrm{O}_{3}$. The choice of deposition method is motivated by the real functionality of produced coating-substrate system, with respect to adhesion of the coating to the substrate [14]. DB IBAD proved to be an effective method in deposition of coatings which are: strongly adherent to substrates and characterized by intrinsic stress of low level of the compressive type [15].

\subsection{EXPERIMENTAL PROCEDURES}

Ti-B coatings were formed on ceramic substrates based on $\alpha-\mathrm{Al}_{2} \mathrm{O}_{3}$ (reinforced by addition of $1 \%$ vol. $\mathrm{MgO}$ ), used for machining of various types of materials (steel, cast iron, non-ferrous metals and alloys) at high cutting speeds, without the use of coolants liquids. As substrates we used commercially available alumina cutting tools inserts in cuboidal form (12 mm x $12 \mathrm{~mm} \times 7 \mathrm{~mm}$ ), prepared at IOS Institute of Advanced Materials Manufacturing Technologies, Krakow, Poland. The surfaces of the substrates were polished before Ti-B coatings deposition, then cleaned in isopropyl alcohol bath using ultrasonic cleaner, dried and precleaned by $\mathrm{Ar}+$ ion sputtering. Ti-B coating were deposited using $\mathrm{TiB}_{2}$ target produced by Goodfellow (UK) in a form of a disc of $50 \mathrm{~mm}$ in diameter and $3 \mathrm{~mm}$ in thickness. Two 
beams of Ar+ ions of the same energy $\sim 10 \mathrm{keV}$ were used, as is shown at Figure 2. First ion beam was used for sputtering the target and directed to it surface at sputtering angle $\alpha=67^{\circ}$. Second Ar+ ion beam was directed perpendicularly to the surface of substrate and used for ion mixing and densification of growing Ti-B coating. Process was conducted in vacuum $\left(\sim 10^{-6} \mathrm{mbar}\right)$, at The Krupkowski Institute of Nuclear Physics, Polish Academy of Sciences in Krakow, Poland.

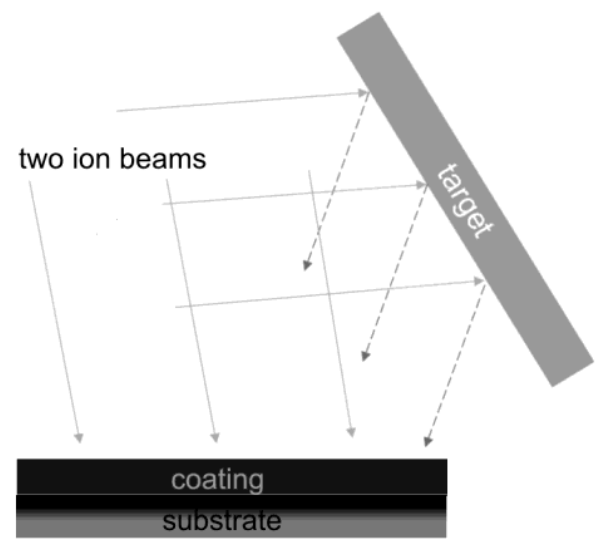

Figure 1. Dual beam IBAD process - a scheme

Chemical bonds were investigated by XPS method using X -ray radiation emitted by Al lamp (K $\mathrm{K}_{\alpha 12}$ line) of energy $1486,6 \mathrm{eV}$ (VSW Scientific Instruments ltd.). The maximum depth of XPS analysis was $\sim 7 \mathrm{~nm}$. The chemical composition of coated samples was examined by EDS (Olympus), accompanied the microstructure examination conducted by electron scanning microscope JEOL JSM (PU of Krakow) of coated samples, before and after cutting test. Mechanical properties of coated and uncoated samples were examined by a diamond tip of Berkovich -type geometry. CSM+ (UST Krakow) system was applied, equipped with a light microscope. The loading and unloading speed was $10 \mathrm{mN} / \mathrm{s}$ (according to PN-EN ISO 14577-1), the applied load was in the range $0.1 \mathrm{mN}$ to $50 \mathrm{mN}$. The hardness $\mathrm{H}$ and elastic modulus E were calculated by Oliver \& Phaar method using load- displacement plots, registered during nanoindentation test. Friction- wear tests of alumina samples coated by Ti$\mathrm{B}$, were conducted in ball-on-disc configuration, using Micro- Combi -Tester (UST Krakow). Examination were realized in accordance with ASTM G99-90 and ASTM G133-02, using alumina or $100 \mathrm{Cr} 6$ steel ball of $1 \mathrm{~mm}$ in diameter (as counterparts) loaded at $1 \mathrm{~N}$. Cutting tests were carried out on MoriSeiki NL2000SY/500 turning machining center in longitudinal finishing turning of steel. The test was conducted at Institute of Advanced Manufacturing Technology, Krakow. The turning center was equipped with a commercial tool holder ensuring the rake angle $\gamma_{0}=-6^{\circ}$, clearance angle $\alpha_{0}=6^{\circ}$, inclination angle $\lambda s=-6^{\circ}$ and side cutting edge angle $\kappa_{\mathrm{r}}=75^{\circ}$. The geometry of the alumina tool inserts was CSRNL/P 2525-12 (Fig. 2).

The chip breaker of PK420 type was applied. As a workpiece material a C45 steel round bar 
was used of an external (initial) diameter of $180 \mathrm{~mm}$ and a length of $600 \mathrm{~mm}$. The hardness of steel was $173 \mathrm{HB}$. Cutting test were performed in air atmosphere, without use of coolant liquid. Tests were carried out with the following parameters: depth of cut up $\mathrm{a}_{\mathrm{p}}=0.5 \mathrm{~mm}$, feed rates $\mathrm{f}=0.1 \mathrm{~mm} / \mathrm{r}$, cutting speed $\mathrm{v}_{\mathrm{c}}=400 \mathrm{~m} / \mathrm{min}$.

\section{RESULTS AND DISCUSSION}

\subsection{COMPOSITION AND MICROSTRUCTURE}

Typical SEM images of the surface of Ti-B coating deposited By DB IBAD on the alumina substrate are shown in Figure 2. Produced coating was continuous and dense by thin enough to be almost transparent to electron beam. In result of low thickness of Ti-B coatings, in EDS analysis strong signals of substrate elements ( $\mathrm{Al}$ and $\mathrm{O}$ ) were mainly detected. The results of EDS analysis of selected areas of the surface of coated sample did not show important differences in the their chemical composition.

a)

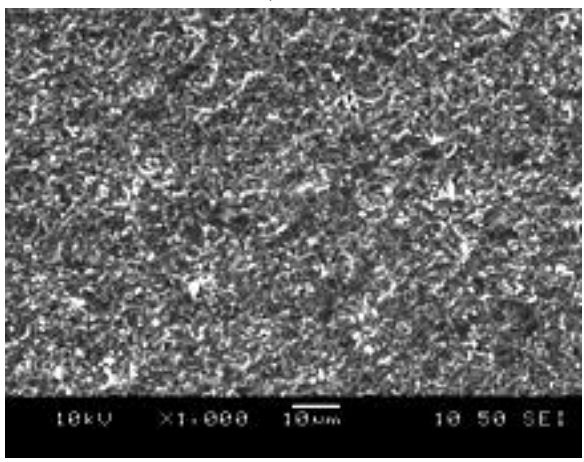

b)

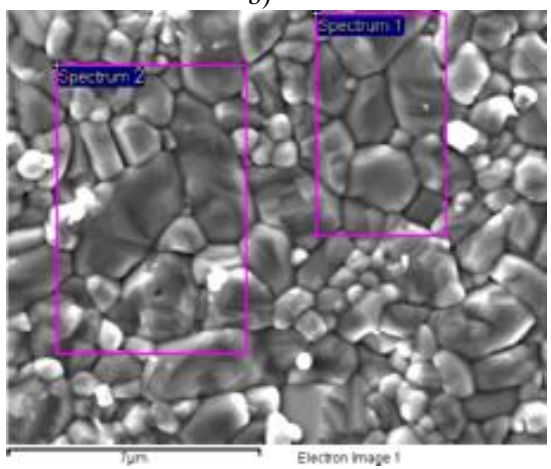

Figure 2. SEM images of the surface of alumina composite after deposition of Ti-B coating by dual beam IBAD method : a) a general view, b) magnified image with marked areas of EDS analysis

Table 1. Results of EDS analysis of alumina substrate after deposition of Ti-B coating, taken at areas marked on Figure $3 b$

\begin{tabular}{|c|c|c|c|c|c|}
\hline Spectrum & $\begin{array}{c}\text { B } \\
\text { [wt. \%] }\end{array}$ & $\begin{array}{c}\text { O } \\
\text { [wt. \%] }\end{array}$ & $\begin{array}{c}\text { Al } \\
\text { [wt. \%] }\end{array}$ & $\begin{array}{c}\text { Ti } \\
\text { [wt. \%] }\end{array}$ & $\begin{array}{c}\text { Total } \\
\text { [wt. \%] }\end{array}$ \\
\hline 1 & 13.3 & 44.2 & 33.1 & 9.4 & 100.0 \\
\hline 2 & 15.1 & 44.2 & 32.0 & 8.7 & 100.0 \\
\hline
\end{tabular}

X-ray photospectroscopy was applied to investigate chemical bonds in Ti-B coating. The maximum depth of XPSs analysis at applied parameters was $7 \mathrm{~nm}$. Figure 3 shows XPS specific spectra of Ti $2 \mathrm{p}$ and $\mathrm{B} 1 \mathrm{~s}$, recorded from at the surface of Ti-B coating. The energy of bonds indicated the presence of titanium diboride $\mathrm{TiB}_{2}$ but also the presence of $\mathrm{TiO}_{2}$ and $\mathrm{B}_{2} \mathrm{O}_{3}$ in the coatings. 
a)

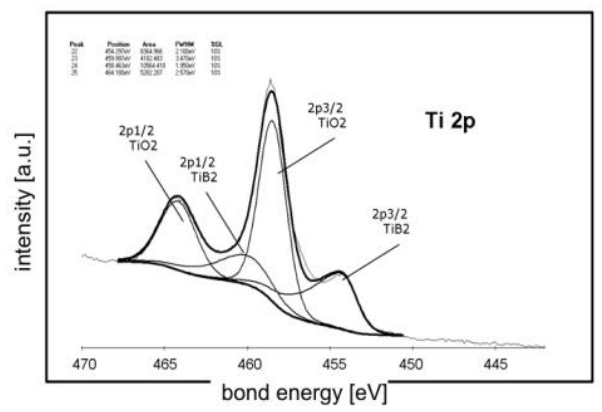

b)

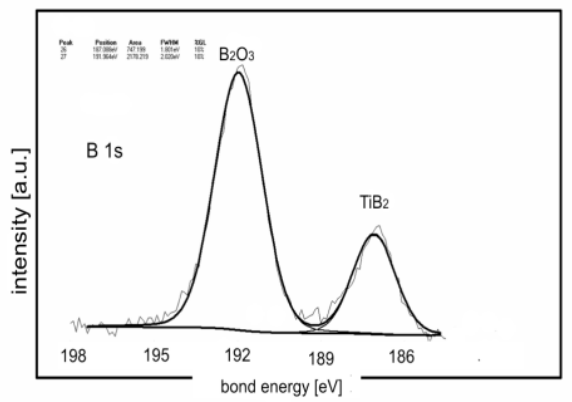

Figure 3. Experimental XPS spectra : a) Ti 2p, b) B 1 s, registered from the surface of Ti-B coating deposited by dual beam IBAD method on alumina substrate

\subsection{MECHANICAL PROPERTIES}

Mechanical properties of coated samples determined in nanoindentation test were enhanced in comparison to uncoated ones. The calculated values of hardness and elastic modulus were influenced by applied load (Fig. 4) and the indentation depth to coating thickness ratio, as shown in Figure 5.

a)

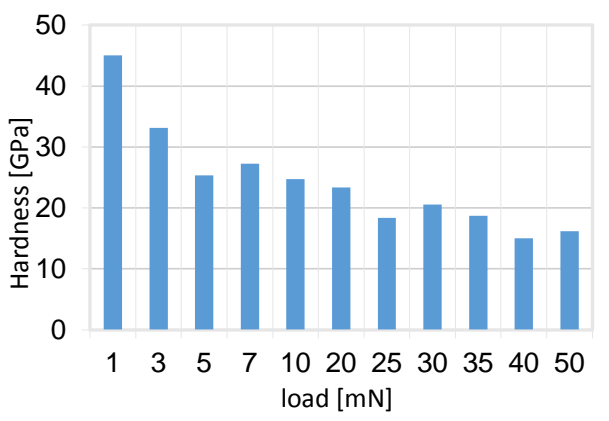

b)

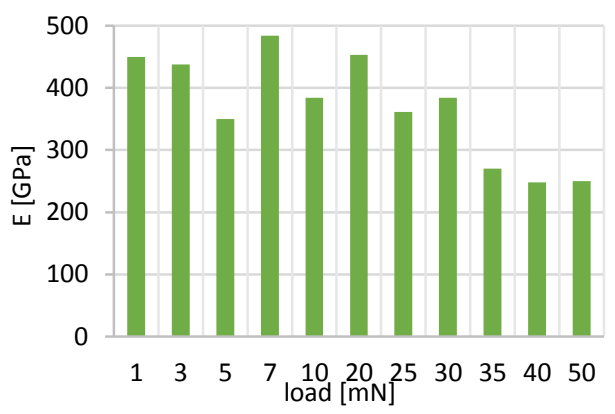

Figure 4. Mechanical properties calculated for alumina composite coated by Ti-B as a function of applied load: a) hardness $\mathrm{H}, \mathrm{b}$ ) elastic modulus $\mathrm{E}$

Even in the smallest load range, i.e. $1-5 \mathrm{mN}$, the indentation depth was higher then $15 \%$ of the thickness of Ti-B coatings (Fig. 5). The highest values of hardness $\mathrm{H}=45 \mathrm{GPa}$ and elastic modulus $\mathrm{E}=450 \mathrm{GPa}$ were calculated at the load of $1 \mathrm{mN}$. The average hardness of Ti-B coated alumina determined on the basis of load- displacement plots registered under loads 1 to $5 \mathrm{mN}$ was $26 \mathrm{GPa}$, the average value of elastic modulus was $380 \mathrm{GPa}$, giving the average $\mathrm{E} / \mathrm{H}$ index of 14.6 , which indicates low susceptibility of the analyzed coating substrate system to plastic deformation. Hardness an elastic modulus calculated for referential alumina substrates (uncoated) was $16.5 \mathrm{GPa}$ and $250 \mathrm{GPa}$, respectively. 


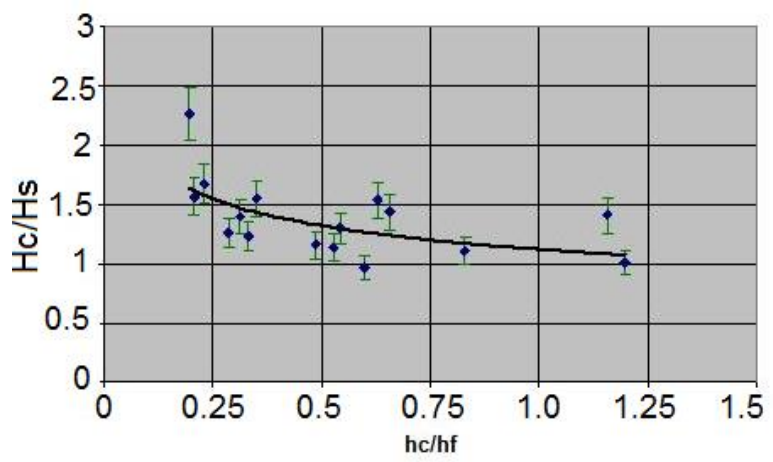

Figure 5. The influence of applied load on the hardness Hc and elastic modulus E calculated for alumina composite coated by Ti-B with respect to the hardness of uncoated alumina Hs and indentation depth hc and coating thickness hf

\subsection{FRICTION AND WEAR PERFORMANCE}

In the friction contact with the alumina ball, the coefficient of friction COF of alumina substrates with Ti-B coating did not reach 0.7 (Fig. 6a), in the case of the steel ball used as the counterpart COF was less than 0.6 (Fig. 6b). Two wide (or three) stages were distinguished on friction coefficient vs. normal force plots. In friction contact with alumina ball first, initial rapid increase from 0.15 to 0.5 was observed, followed by a continuous slight increase to the value of $\sim 0.6$. In friction contact with steel ball, COF of coated sample initially arise rapidly from 0.1 to 0.4 , then continuously - from 0.4 to 0.58 to reach the steady-state at the value $\sim 0.6$.

a)

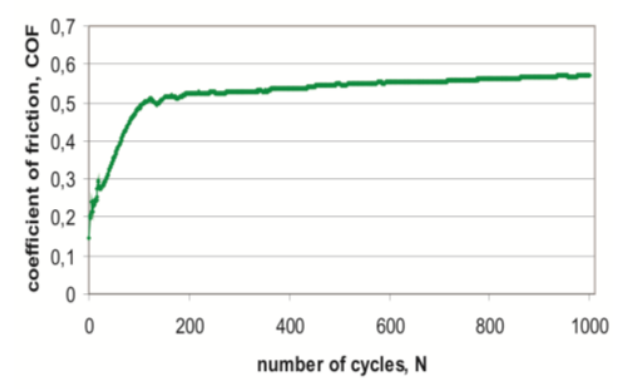

b)

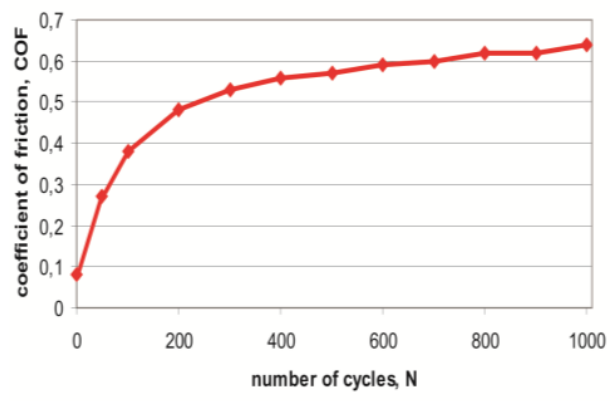

Figure 6. The of friction coefficient of alumina coated by Ti-B versus number of cycles plot registered in ball-on-disc test with: a) $\mathrm{Al}_{2} \mathrm{O}_{3}$ ball, b) $100 \mathrm{Cr} 6$ steel ball (each of $1 \mathrm{~mm}$ in diameter loaded at $1 \mathrm{~N}$

Figure 7a shows OM image of the surface of Ti-B coatings in the area of tracks produced in ball-on disc test conducted with the steel ball used as counterpart to be only slightly worn. Detailed observations of the microstructure of produced tracks by SEM allowed to identify the mechanisms of wear of Ti-B coatings much more precisely. The wear mechanism 
of coatings tested with alumina ball was of abrasive type, while in the case of the steel ball of a mixed type: abrasive and adhesive. As shown in Figure 7b, during the ball-on-disc test, steel was rubbed into the tracks. EDS maps of $\mathrm{Fe}$ and $\mathrm{Al}$, presented on Figures $7 \mathrm{c}$ and $7 \mathrm{~d}$ show clearly the differences in the surface distribution of this elements, indicating rubbed areas as enriched in iron. Having in a mind the difference in mechanical properties of materials being in friction contact this phenomenon is not surprising. The hardness of $100 \mathrm{Cr} 6$ steel is almost 4 times lower then alumina and $\sim 12$ times lower than the hardness of $\mathrm{TiB}_{2}$. But this test gave us an important information: a possible adhesion of steel to the surface of Ti-B coated alumina tool. As steel and cast iron are the main group of materials to be cut by the tool, observed adhesive mechanism of the wear is deleterious. It usually results in the formation of accretions on the tool tip which change the geometry of cutting. During machining the built-up material detaches periodically with a piece of the tool or the coating thus accelerates a damage process of the tool and causes a decrease in surface roughness of the workpiece.

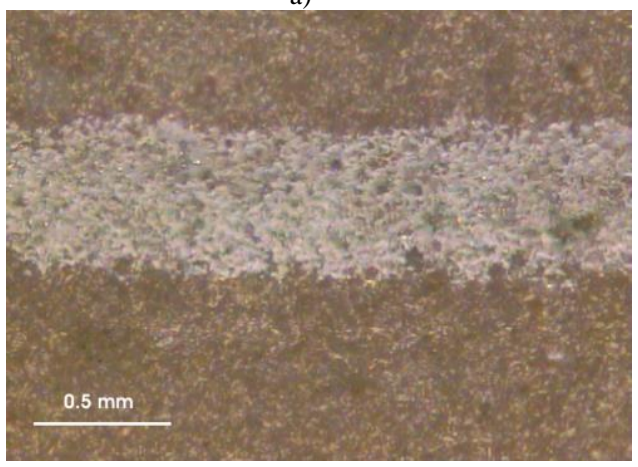

c)

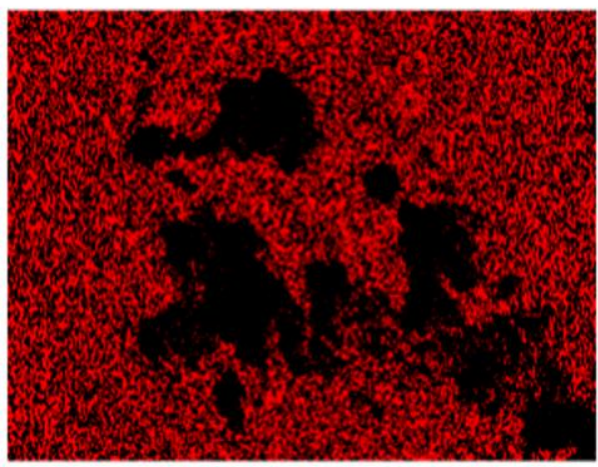

100 um

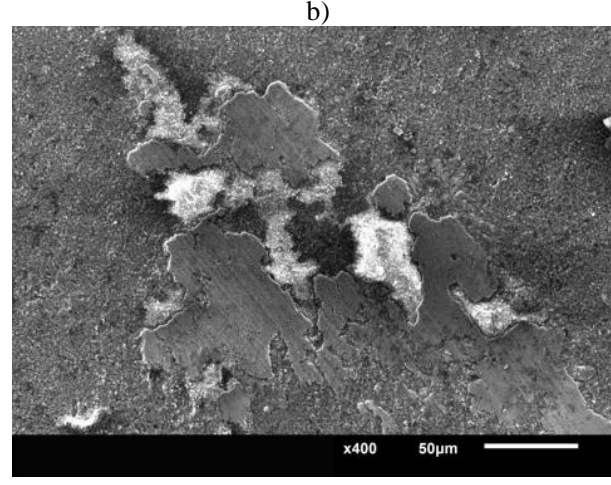

d)

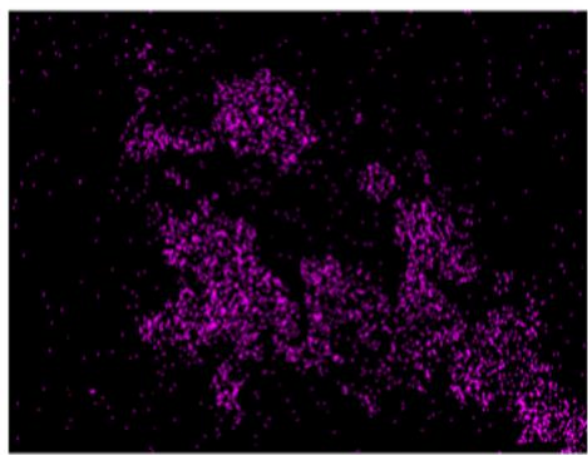

$\mathrm{Fe} \mathrm{K} \alpha$

Figure 7. a) OM and b) SEM images of worn area of Ti-B coating deposited on the surface of alumina composite with corresponding EDS maps showing surface distribution of : c) Al, d) Fe. 
The lowered friction coefficient of boron- and titanium-rich materials comes from oxidation reactions which are activated thermally (by friction) during machining in humidity environment $[7,10]$. In the case of boron present on the friction contact, $\mathrm{H}_{3} \mathrm{BO}_{3}$ is the main product of the oxidation reaction, conducted in low temperatures $\left(<100^{\circ} \mathrm{C}\right)$. When temperature arise above $100-130^{\circ} \mathrm{C}$, boric acid gradually loses water and pass to metaboric acid $\mathrm{HBO}_{2}$, with accordance to reaction 1 .

$$
2 \mathrm{H}_{3} \mathrm{BO}_{3} \stackrel{130 \mathrm{C}}{\longrightarrow} 2 \mathrm{HBO}_{2}+2 \mathrm{H}_{2} \mathrm{O}
$$

Additional heating causes reduction reaction of metaboric acid (at $\sim 150^{\circ} \mathrm{C}$ ) and $\mathrm{B}_{2} \mathrm{O}_{3}$ is produced (reaction 2). But in oxygen - rich environment the inverse reaction is possible. When the temperature at interface reach the melting point of boron trioxide $\left(\sim 550^{\circ} \mathrm{C}\right)$ a liquid phase is formed [12].

$$
6 \mathrm{HBO}_{2} \stackrel{\text { heating }}{\longrightarrow} 3 \mathrm{~B}_{2} \mathrm{O}_{3}+3 \mathrm{H}_{2} \mathrm{O}
$$

The presence of $\mathrm{B}_{2} \mathrm{O}_{3}$ liquid phase serves as coolant lubricant at the surface of friction-wear contact. This effect was called in literature as "self adaptation" is of marginal importance for wear performance of alumina- base sinters, produced with addition of titanium diboride, because they contain max. $8-10 \%$ vol. of $\mathrm{TiB}_{2}$. This volume fraction of titanium diboride provides increased hardness without significant decrease in its toughness, but boron content is too low to produce a sufficient amount of oxide products, capable to reduce the friction. During machining, oxide film is quickly removed from the surface of that tools by abrasion and evaporation, since the friction causes a rapid arise of the temperature at contact area. Therefore the liquid phase is not observed in worn area of sintered alumina- $\mathrm{TiB}_{2}$ cutting tools [6].

In contrast, in Ti-B coatings boron content is high enough of to ensure a sufficient amount of oxides produced in chemical reaction with humidity, to form a tribofilm, which is able to enhance the wear performance of the alumina cutting tool (Fig. 8).

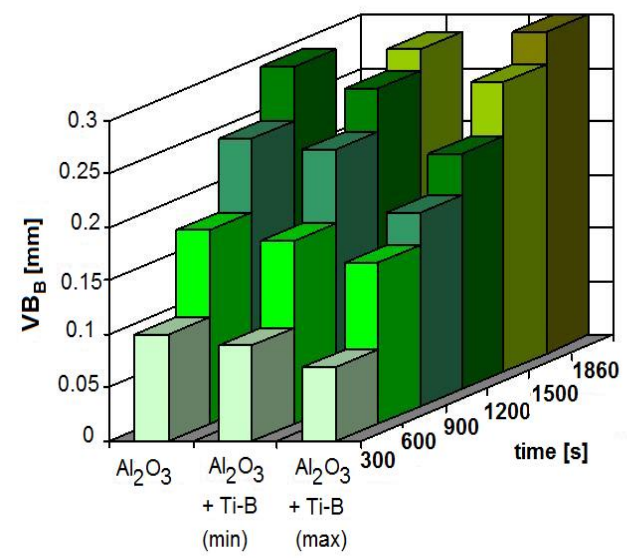

Figure 8 . The durability of alumina cutting inserts uncoated and coated by Ti-B, determined in dry turning of $100 \mathrm{Cr} 6$ steel 
The traces of liquid phase which are observed at the edge of coated alumina insert (Fig. 9) indicate that the temperature in the worn area has exceeded the melting point of $\mathrm{B}_{2} \mathrm{O}_{3}$, but was not high enough to cause its complete evaporation from worn area.

a)

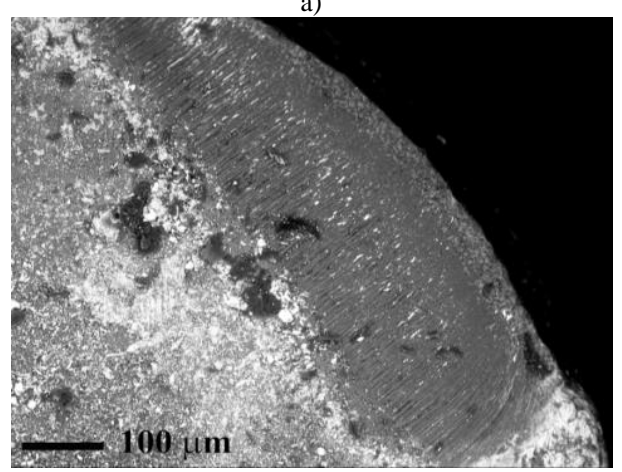

b)

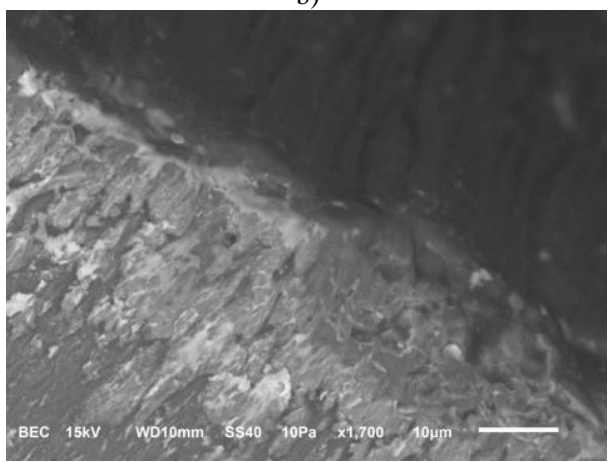

Figure 9. SEM images of the worn rake face of Ti-B coated alumina insert:

a) a general view of crater, b) magnified image of the edge with traces of liquid

The wear mechanism of alumina inserts coated by Ti-B, the wear mechanism was of abrasive type only. There were no traces of Fe in crater area which could indicate adhesion of the steel (used as a workpiece material). The results of cutting test confirms the positive impact of Ti$\mathrm{B}$ coating on dissipation of heat generated in friction contact area and in result on frictionwear performance of alumina-base cutting tools. Due to the small thickness of deposited Ti-B coatings, the beneficial effect is not very impressive, but can be easily magnified by extending the time of DB IBAD deposition process or by the use of another, more effective PVD method.

\section{CONCLUSIONS}

Ti-B coatings produced by DB IBAD method on alumina inserts are dense and smooth, but their thickness is small and non uniform and decreases continuously with the distance from the tip of the tool.

The presence of Ti-B coating was beneficial for both hardness and wear performance of alumina cutting tools. The hardness of Ti-B coated alumina inserts was increased up to 3 times value calculated for uncoated ones. The durability of coated samples was almost $150 \%$ the value for uncoated alumina sinters.

The positive impact of Ti-B coatings on friction-wear properties of alumina cutting tools was confirmed in cutting test. The wear mechanism of coated and uncoated alumina inserts was correct - of abrasive type.

The traces of the liquid phase rich of oxygen were easy visible at the edge of cutting tool in worn area and are related to oxidation reaction of boron with humidity leading to creation of $\mathrm{B}_{2} \mathrm{O}_{3}$

Ti-B coatings are of high potential in cutting tool design but have to be produced much more effectively with respect to their thickness homogeneity and reasonable speed of deposition. 


\section{AKNOWLEDGMENTS}

Presented work was realized within the program BRIDGE (POMOST 13-8/13) under the Foundation for Polish Science project „Mono- and multilayered, multiphase coatings based on $\mathrm{TiB}_{2}$ for wear-resistant application" co-financed by European Union under European Found for Regional Development "Innovative Economy".

The Author is grateful to dr Boguslaw Rajchel (INP PAS, Krakow) for deposition of Ti-B coatings, dr Marcin Kot and dr Agnieszka Radziszewska (UST, Krakow) for tribo-mechanical tests and dr Kazimierz Czechowski (IAMT, Krakow) for cutting test of the samples.

\section{REFERENCES}

[1] KIMURA I., HOTTA N., HIRAOKA Y., SAITO N.: Sintering and characterization of $\mathrm{Al}_{2} \mathrm{O}_{3}-\mathrm{TiB}_{2}$ composites, Journal of the European Ceramic Society 51 (1989), p. 23-27.

[2] DOBRZANSKI L.A., MIKUŁA J.: Structure and properties of $\mathrm{PVD}$ and $\mathrm{CVD}$ coated $\mathrm{Al}_{2} \mathrm{O}_{3}+\mathrm{TiC}$ mixed oxide tool ceramics for dry on high speed cutting processes, Journal of Materials Processing Technology 164-165 (2005), p. 822-831.

[3] GRZESIK W.: Podstawy skrawania materiałów konstrukcyjnych, WNT Warsaw (2010),

[4] JIANXIN D., XING A., Effect of TiB ${ }_{2}$ particle and $\mathrm{SiC}$ whisker additions on the friction and wear behaviors of $\mathrm{Al}_{2} \mathrm{O}_{3}$ ceramic. Journal of Advanced Materials 274 (1996), p. 32-36.

[5] MUNRO R.G.: Materials Properties of Titanium Diboride. Journal of Research of the National Institute of Standards and Technology 1055 (2000), p.709.

[6] JIANXIN D., TONGKUN C., LILI L.: Self-lubricating behaviors of $\mathrm{Al}_{2} \mathrm{O}_{3} / \mathrm{TiB}_{2}$ ceramic tools in dry high-speed machining of hardened steel, Journal of the European Ceramic Society' 25 (2005) p. 1073-10795.

[7] BERGER M., LARSSON M., HOGMARK S.,: Surface and Coating Technology 124 (2000), p. 253-261,

[8] VOEVODIN A. A., ZABINSKI J. S.: Supertough wear resistant coatings with "chameleon" surface adaptation. Thin Solid Films 370 (2000), p. 223-231.

[9] LIU Y., ERDEMIR A., MELETIS E.I.: An investigation of the relationship between graphitization and frictional behavior of DLC coatings. Surface and Coating Technology 86-87(1996), p. 564- 568.

[10] TALLANT D.R., PARMETER J.R., SIEGAL M.P., SIMPSON R.L.: The thermal stability of diamond-like carbon. Diamond And Related Materials 4 (1995), p.191-199,

[11] ERDEMIR A., BINDAL C., ZUIKER C., SAVRUN E.: Tribology of naturally occurring boric acid films on boron carbide, Surface and Coatings Technology 86-87 2 (1996), p. 507-510.

[12] SEVIM F., DEMIR F., BILEN M., OKUR H.: Kinetic analysis of thermal decomposition of boric acid from thermogravimetric data, Korean Journal of Chemical Engineering 23,5, (2006), p. 736-740.

[13] ZHANG Y., DING G.P., ZHOU Y.C., CAI B.C: $\mathrm{Ti}_{3} \mathrm{SiC}_{2}-a$ self lubricating ceramic. Materials Letters 55 (2002), p. 285-289.

[14] RAUSCHENBACH B.: Ion beam assisted deposition - a processing technique for preparing thin films for high-technology applications, Vacuum 69 (2003), p. 3-10.

[15] TWARDOWSKA A., RAJCHEL B., SZUTKOWSKA M., ZIMOWSKI S.: Tribological behavior of AISI 316L steel after deposition of Ti-Si-C/Ti-B coatings by dual beam IBAD method, Inżynieria Materiałowa" 04194 XXXIX Sigma-NOT (2013), p. 186. 